\title{
LEGAL FRAMEWORK FOR THE PROTECTION OF CHILD RIGHTS IN NIGERIA ${ }^{1}$ \\ O. I. Tajudeen
}

\author{
Tajudeen Ojo Ibraheem \\ LL. B (Hons), B.L, LL. M (Ife) C.O.M, AMNIM, MBLAS, Notary Public \\ Senior Lecturer, Faculty of Law, Adekunle Ajasin University, Akungba Akoko, \\ Ondo State. Nigeria. \\ E-mail: taju.ibraheem@yahoo.com; G.S.M No.: +2348023362799
}

\begin{abstract}
$^{2}$
As far as human rights law is concerned, children constitute a minority group. They are by their nature very vulnerable and thus merit special laws to cater for their needs as the well-being of generations to come depend on how well children are raised today. The writer takes a look at the Nigerian legal system as it relates to children. It examines the UN CRC and the Nigerian CRA 2003.
\end{abstract}

Keywords: child, children, law, Nigeria, rights

Introduction - who is a child?

The United Nations Convention on the Rights of the Child defines a child as "a human being below the age of 18 years unless under the law applicable to the child, majority is attained earlier"3. The various Children and Young Persons enactments in Nigeria on the other hand define 'child' as a person who has not attained the age of 14 years and 'young person' as one who has attained the age of 14 years but has not attained the age of 17 years. http://en.wikipedia.org/wiki/Child - cite_note-un-3 Children generally have fewer rights than adults and are classed as not able to make serious decisions, and legally must always be under the care of a responsible adult. In some cases, the age at which a person ceases to be a child varies even under different laws in the same country. However, for the purposes of this write-up, the word child covers both children and young persons.

\section{Why children?}

Children are the assurance of the continuity of the human society. Without children today there will be no society of humans' tomorrow. Yet they are the most vulnerable members of the society. They lack the physical, emotional and mental maturity required to face life. They, therefore, require special safeguards, care and

${ }^{1}$ TAJUDEEN OJO IBRAHEEM, LL. B (Hons), B.L, LL.M (Ife) C.O.M, AMNIM, MBLAS, Notary Public, Senior Lecturer, Faculty of Law, Adekunle Ajasin University, Akungba Akoko, Ondo State. Nigeria. E-mail: taju.ibraheem@yahoo.com; G.S.M No.: +2348023362799

2 This paper originally constituted a chapter in the writer's M. Phil thesis submitted to the Faculty of Law, Obafemi Awolowo University, Osun State, Nigeria. It has subsequently been abridged for the purpose of this publication.

3 "Convention on the Rights of the Child" The Policy Press, Office of the United Nations High Commissioner for Human Rights, http://www.hakani.org/en/convention/convention_rights_child.pdf 
protection. In addition, children are unique by their nature and their needs and as such the normal rights guaranteed adults are not adequate to cater for the special needs of children. ${ }^{4}$

Again, the kind of leaders we will have tomorrow depends on the kind of children we have today. Abused, maltreated and neglected children become stunted emotionally and physically, and lack the confidence to face life. They are therefore deprived of the opportunity to develop their full potentials. ${ }^{5}$

Since the independence of Nigeria, rivalries between groups of the population have regularly turned into violent conflicts. Many children died, or lost their parents, or were left disabled or were internally displaced. Children have also been severely affected by the economic crises faced by the country in 1999 which has led to an increase in the number children living in poverty or extreme poverty. Among other dangerous consequences, poverty made more children to live and/or work in the street and has increased their vulnerability to trafficking.

Some diseases have reached tragic dimensions and harmful traditional practices, such as forced marriage, female genital mutilation, widowhood practices and boy preference continue to have negative effects on the life and welfare of the girl-child. But discrimination also affects other groups of children, such as orphans, street children, disabled children or children born out of wedlock. A large number of children also continue to be subjected to domestic violence or corporal punishment at school or in detention facilities. Thus millions of Nigerian children face special problems of disadvantage, discrimination, abuse and exploitation, sometimes in appalling circumstances. These problems not only compound the risks of survival and create formidable obstacles for the development of children, but are major challenges in their own right; requiring special protective measures if they are to be addressed effectively.

\section{The legal system and the Laws applicable to children}

The general framework within which human rights are protected in Nigeria is enshrined in the 1999 Constitution of the Federal Republic of Nigeria. Chapter IV contains an elaborate Bill of Rights. The rights guaranteed include the right to life (Sec. 33); the right to personal liberty (Sec. 35); the right to fair hearing (Sec. 36) and the right to freedom of movement (Sec. 41). Section 42 prohibits unjustifiable discrimination on the basis of "ethnic group, place of origin, sex, religion or political opinion".

The 1999 Nigerian Constitution provides in its Chapter Two some fundamental objectives and directive principles of the Nigerian State which are geared towards the promotion and protection of children's interests in Nigeria. The Constitution requires the government to provide free compulsory and universal primary education, free secondary education, free university education, and free adult literacy programs when practicable. ${ }^{6}$ Section 13 imposes a Constitutional obligation on all arms and tiers of government to observe the fundamental objectives relating to socio-political, economic, educational and cultural matters. Section 14 provides that the security and welfare of the people shall be the primary purpose of government. Section 16 provides for the control of the economy

\footnotetext{
4 http://dailyindependentnig.com/2013/10/the-child-rights-act-2003-the-rights-the-benefits/. Accessed on $11 / 03 / 15$

5 http://dailyindependentnig.com/2013/10/the-child-rights-act-2003-the-rights-the-benefits/. Accessed on $11 / 03 / 15$

${ }^{6}$ See Section 18 of the 1999 Constitution.
} 
to secure maximum welfare, freedom and happiness of every citizen on the basis of social justice, equality of status and opportunity, harnessing and distribution of material resources of the community to serve the common good, provision of suitable and adequate shelter, suitable and adequate food for all Nigerians by the State.

Under section 17, the State social order is to be founded on freedom, equality and justice and the State shall direct its policy towards ensuring that:

(a) all citizens without discrimination on any ground whatsoever have opportunity for securing adequate means of employment;

(b) conditions of work are just and humane, and that there are adequate facilities for leisure and for social, religious and cultural life;

(c) the health, safety and welfare of all persons in employment are safeguarded and not endangered or abused;

(d) there are adequate medical health facilities for all persons;

(e) there is equal pay for all work without discrimination on account of sex, or any other ground whatsoever;

(f) Children and young persons and the aged are protected against any exploitation whatsoever, and against moral and material neglect.

However, these provisions are only directive principles of State Policy and no action can be brought against the government for enforcement of the provisions as they are not justiciable.

Nigeria's legal system is characterized by three different traditions of law: The English Common Law, Islamic or Shari'ah Law and Customary Law. The 1999 Constitution provides, in section 6 , for an independent judiciary for the determination of any question as to civil rights and obligations. The Constitution equally allows for the Customary and Shari'ah courts to cover various issues and jurisdictions. The Shari'ah courts according to section 277 (1) (2) of the 1999 Constitution have jurisdiction in civil proceedings involving questions of Islamic personal law regarding marriage concluded in accordance to that law and relating to family relationship or the guardianship of an infant; where all the parties to the proceedings are Muslims. The Customary courts' jurisdiction as provided for in section 282 (1) (2) relates to civil proceedings involving questions of Customary Law and succession as may be prescribed by the House of Assembly of the State.

Nigeria ratified the Convention on the Rights of the Child (hereafter the CRC) on April $16^{\text {th }} 1991$ and has ratified subsequently other international instruments such as the Convention on the Elimination of all Forms of Discrimination Against Women (CEDAW), the Convention Against Torture and Other Cruel Inhuman or Degrading Treatment or Punishment and the Convention on the Elimination of All Forms of Racial Discrimination. It is also a party to the International Covenant on Civil and Political Rights and the International Covenant on Economic, Social and Cultural Rights. In addition, Nigeria has ratified the African Charter on Human and People's Rights. Further, it signed but did not ratify the Optional Protocol on Children in Armed Conflict and the Optional Protocol on the Sale of Children, Child Prostitution and Child Pornography and the African Charter on the Rights and Welfare of the Child.

As for penal infraction, Nigeria has two separate codes, one applicable to Southern Nigeria (Criminal Code) and another applicable to Northern Nigeria (Penal 
Code). These provide for offences against persons and the State, including homicide, assaults and different kinds of sexual and gender- specific violations such as rape.

Since the ratification of the CRC, the AU Charter on the Rights and Welfare of the Child and other relevant international instruments, Nigeria has instituted various legislative and institutional measures aimed at addressing various forms of violence against children. These enacted legislations include The Child's Rights Act (CRA) 2003 and Trafficking in Persons (Prohibition) Law, Enforcement and Administration Act 2003.

The Government of Nigeria has also evolved some institutions charged with child protection issues and protection against violence. These include: National and State Child Right Implementation Committees; Child Development Departments in the Federal and State Ministries of Women Affairs; National Council of Child Rights Advocates of Nigeria (NACCRAN) as the umbrella NGO involved in Child Rights advocacy; Nigerian Children's Parliament and the National Agency for the Prohibition of Trafficking in Persons.

In Nigeria, there are laws which expressly prohibit child labour. For instance, the Labour Act $^{7}$ in section 59 sets the minimum age for employment at 15 years except for light agricultural, horticultural, or domestic work performed for the family. The minimum age provided for apprenticeships under Section 49 of the Act is 13 years. It means that any person below the age of 13 is not supposed to work as an apprentice. Children are prohibited from being employed to lift or carry any load likely to negatively affect their physical development. The Labour Act generally provides for the prohibition of hazardous works by children.

\section{The Convention on the Rights of the Child (CRC)}

The United Nations CRC is a human rights treaty which sets out the civil, political, economic, social, health and cultural rights of children. Two optional protocols to the convention were adopted on $25^{\text {th }}$ May 2000. The first restricts the involvement of children in military conflicts while the second prohibits the sale of children, child prostitution and child pornography.

The convention deals with child-specific needs and rights. Under it, States are required to act in the best interests of the child. This approach is different from that previously existing in many societies where children are treated as possessions or chattels.

Nigeria has ratified the CRCand as such is obligated under Article 4 of the CRC to undertake all appropriate legislative, administrative and other measures for the implementation of the rights recognised in the present convention. As with any international treaty, State parties need to consider whether becoming a party to these human rights treaties will require changes to be made to their national laws or policies, to enable them meet all of their obligations under the treaties. For example, some legislative measures may need to be taken with regard to child rights and the system of juvenile justice in line with the provisions of the above treaties to which Nigeria is a signatory.

The concept of participation is part of the culture of democracy. The rights of children to participation are grounded in the idea that, like any other human beings, they have the right to share in the making of decisions which affect their lives and the life of the community of which they are part. In the CRC, Articles 12-15 capture what have

\footnotetext{
${ }^{7}$ Cap L1, LFN 2004.
} 


\section{O. I. Tajudeen}

collectivity been regarded as the participatory rights of children. Article 12 provides that the child has the right to express his or her opinion freely and to have that opinion taken into account in any matter of procedure affecting the child. Article 14 binds state parties to respect the child's rights to freedom of thought, conscience and religion, subject to appropriate parental guidance.

In a bid to more effectively implement the $\mathrm{CRC}$, among other reasons, the Nigerian Government enacted the Child Rights Law 2003.

\section{The Child Rights Act (CRA) 2003}

This Act seeks to set out the rights and responsibilities of the child in Nigeria and provides for a system of child Justice Administration and the care and supervision of children, amongst other things.

Within the context of such a mandate, therefore, the Act has been divided into twenty-four parts and eleven schedules. The various parts address broadly rights and responsibilities, protection and welfare of children, duties and responsibilities of government, institutions for children, as well as other miscellaneous matters. In terms of contents, the Nigerian Child Rights Act borrowed a leaf from the UN CRC and the OAU Charter in respect of the guiding principles for the promotion and protection of the rights of children.

Under sections 1-2 (Part I), the Act provides that the best interest of the child shall be of primary or paramount consideration in all actions to be undertaken whether by an individual, public or private body, institutions or service, court of law or administrative or legislative authority. Further, the Act provides that necessary protection and care shall be given to the child for his/her well-being, taking into account the rights and duties of the child's parents, legal guardians and other bodies legally responsible for the child.

Part II (Sections 3-20) of the Act provides for the rights and responsibilities of a child in Nigeria. Accordingly, it entrenches the following fundamental rights of the child, namely, the rights to survival and development, to a name, to freedom of association and peaceful assembly, to freedom of thought, conscience and religion, to private and family life, to freedom of movement, to freedom from discrimination, to dignity of the child, to leisure, recreation and cultural activities, to health and health care services, to parental care, protection and maintenance, to free, compulsory and universal primary education, as well as encouragement of the child to attend and complete secondary education. ${ }^{8}$ The Act also guarantees the right to special protection measures for a child in need of such protection as is appropriate to his/her physical, social, economic, emotional and mental needs and under conditions which ensure his/her dignity, promote the child's self-reliance and active participation in the affairs of the community, as well as the provision to a child with such assistance and facilities necessary for the child's education, training, employment, rehabilitation and recreational opportunities in a manner conducive to the child's overall development. Further, the right of an unborn to protection against any harm or injury caused willfully, recklessly, negligently or through neglect before, during or after the birth of that child; and to benefit from the estate of the deceased parents if any one of them dies intestate, having survived any one of them. Furthermore, the Act provides for the contractual right of a child only for necessaries, and any contract entered into by a child below the age of legal majority, that is, 18 years, for repayment of money

\footnotetext{
${ }^{8}$ This is consistent with Chapter Two of the 1999 Nigerian Constitution.
} 
lent or for payment of goods supplied, shall be void. Section 19 provides that subject to age, ability and other legal limitations, every child in Nigeria shall work towards the cohesion of his/her family and community; respect his/her parents and elders at all times and assist them in case of need; serve the Federal Republic of Nigeria by placing physical and intellectual abilities at service; contribute to the moral well- being of the society; preserve and strengthen social and national solidarity, the independence and integrity of Nigeria, the solidarity and achievement of Nigerian, African and World unity, peace, security, freedom, equality and justice for all persons; and to relate with other members of the society, with different cultural values in the spirit of tolerance, dialogue and consultation.

The duty to provide the necessary guidance, discipline, education and training for the child in one's care in order to secure the necessary assimilation, appreciation and observance of the Child's responsibilities (mentioned above) lies on every parent, guardian, institution, persons and authority responsible for the care, maintenance, upbringing, education, training, socialization, employment and rehabilitation of the child. ${ }^{9}$

Part Ill (sections 21-40) of the CRA provides for the protection of the rights of the child through the prohibition of: child marriage, child betrothal, infliction of tattoos and skin marks, exposure to use, production, trafficking, etc. of drugs and psychotropic substances, use of children in any criminal activity, abduction and unlawful removal and transfer of a child from lawful custody, forced, exploitative or hazardous child labour, including outlawry of employment of children as domestic helps outside their own home or family environment, buying, selling, hiring or otherwise dealing in children for the purpose of hawking, begging for alms, prostitution, unlawful sexual intercourse, other forms of sexual abuse and exploitation prejudicial to the welfare of the child.

Further, the Act prohibits recruitment of children into the Armed Forces of Nigeria, and importation of harmful publication which portray information such as the commission of crimes, acts of violence, obscene, immoral and indecent representations which tends to corrupt or deprave a child; whilst the Act further preserves the continued application of all criminal law provisions securing the protection of the born or unborn child.

Part IV (sections 41-49) Act provides for additional protection through civil and welfare proceedings. Thus, it makes provisions for securing assessment orders in relation to the ascertainment of state of health or development of, or the way in which the child has been treated, with a view to enabling a determination as to whether the child is suffering or is likely to suffer significant harm, and to this end, the appropriate authority may secure an order from the family court for emergency protection of children where and when necessary. The Act additionally imposes duties on a State government to safeguard or promote the welfare of any child in danger or suspected to be in danger of suffering significant harm within its jurisdiction.

Part V (Sections 50-52) empowers a Child Development or Police Officer or any other authorized person to bring a child in need of care and protection before a court for a corrective order, if he has reasonable grounds for believing that the child is an orphan or is deserted by his relatives, neglected, ill-treated or battered by his parent or guardian or custodian, or found destitute, wandering, homeless, or surviving parent undergoing imprisonment, mentally disordered, or otherwise severally handicapped; or found

\footnotetext{
${ }^{9}$ Ibid. section 20.
} 


\section{O. I. Tajudeen}

begging for alms, in company of a reputed/common thief or prostitute, or otherwise beyond parental control or exposed to moral or physical danger.

Part VI (Sections 53-62) provides for the making of care and supervision orders which are designed to place children in need of care and protection in the care of a designated person, appropriate authority or state government for the purpose of safeguarding or promoting the welfare of the child. The Supervision Orders may include Education Supervision Orders.

Part VII (Sections 63-67) empowers the Court to give direction or order for the use of scientific tests, including blood tests, to ascertain whether the tests show that a party to any civil proceedings is or is not the father or mother of that person; and for the taking of blood or other samples from that person, the mother or father or any party alleged to be the father or mother of that person or from any two of those persons,

The person responsible for carrying out blood tests taken for the purpose of determining the maternity or paternity of the person in the proceedings, shall make a report to the court stating the result of the tests, and indicating whether the party to whom the report relates is or is not the father or mother of the person whose paternity or maternity, as the case may be, is to be determined, and the value, if any, of such a result. The report shall be received by the court as evidence in the proceedings of the matters stated in the report.

Consent is required to be obtained from any person responsible for the child or the legal guardian if the child is under sixteen years, or is mentally retarded, or is incapable of understanding the nature and purpose of the scientific tests before such a scientific sample is taken from him or her. The appropriate minister is empowered by the Act to regulate the taking, identification and transporting of the scientific samples.

Part VIII (Sections 68-81) deals with possession and custody of children, within the context of the acquisition of parental or quasi-parental authority over children. Where the father and mother of a child were not married to each other at the time of the birth of the child, the family court established under section 153 of this Act may on the application of the father or mother, order that he or she shall have parental responsibility for the child, or the father and mother may by agreement have joint parental responsibility for the child.

The fact that a person has, or does not have, parental responsibility for a child shall not affect any obligation which he may have in relation to the child, including a statutory duty to maintain the child.

The court may make an order as it may deem fit to ensure that the child is brought up in the religion in which the parent requires the child to be brought up, on the application by the parent for the production or custody of a child if it is of the opinion, that the parent ought not to have the custody of the child, and that the child is being brought up in a different religion other than that in which the parent has brought up the child.

The appropriate Minister may, by order, notwithstanding any customary law to the contrary, prohibit the giving or acquiring of the custody, possession, control or guardianship of a child or the removal of a child from any part of a state. It shall be a defence to prove that the child concerned was acquired or given in accordance with customary law, provided that the customary law is not repugnant to natural justice, morality or humanity or inconsistent with any written law. 
Part IX (Sections 82-92) provides for guardianship of children, which is also another way of acquiring parental responsibility for the child. The parents of a child shall have guardianship of the child and, in the event of the death of a parent; the surviving parent shall be the guardian of the child. Where the parents of a child are not fit to be guardians of a child jointly or severally, the court shall, on application of a member of the family or an appropriate authority, appoint a person to be a joint guardian with the parent (s) of the child.

Part X (Sections 93-99) deals with ward-ship, which is a device by which a child is made a ward of court, notwithstanding that the child continues to remain with his parents or under the supervision of a child development officer or some other authority.

Part Xl (Sections 100 -124) provides for fostering of children who are abandoned by their parents, or where an orphaned child is deserted by his relatives, or voluntarily presented by his relatives for fostering, or where neglected or ill-treated by the person having care and custody of him; or has a parent or guardian who does not or cannot exercise proper guidance over him; or is found destitute or is found wandering, has no home or settled place of abode, is on the streets or other public place, or has no visible means of subsistence. The court may dispense with any consent required if it is satisfied that the person whose consent would have been required has abandoned, neglected or persistently ill-treated the child; or cannot be found or is incapable of giving his consent or is unreasonably withholding his consent. Furthermore, the Act prohibits the following acts: receiving money or reward as inducement to foster a child; the taking or sending of a fostered child out of jurisdiction or Nigeria; withdrawal of a child from the care of the applicant without the leave of the court.

Part XII (Sections 125-148) provides for adoption, with the establishment of adoption service nationally and clear specifications for the mechanisms and procedure for adoption, including a well-articulated in built monitoring mechanism, which has led to restrictions on inter-state adoptions. A child may be adopted if the parent(s) or guardian consents to the adoption; or the child is abandoned, neglected or persistently abused or ill-treated, and there are compelling reasons in the interest of the child why he should be adopted. A court order allowing the adoption of a child may be granted to: a married couple where each of them has attained the age of twenty-five years, and they are jointly authorised by order to adopt a child; or a married person who has obtained the consent of his spouse; or a single person of thirty-five years old provided that the child to be adopted is of the same sex as the person adopting; and that in all the above cases, the adopter (s) shall be persons found to be suitable to adopt the child in question by the appropriate investigating officers.

The CRA provides for the establishment of the Family Court, Child Minding or Day Care Centres and Allied Homes under Parts XIII to XIX (Sections 149-203). Under part XIII of the Act, the Family Court, which will operate at the High Court and Magisterial levels, has been vested with the jurisdiction to hear all cases in which the existence of a legal right, power, duty, liability, privilege, interest, obligation or claim in respect of a child is in issue, and any criminal proceeding relating to any offence committed by a child. The court is constrained in all proceedings to be guided by the "principle of conciliation of the parties" involved or likely to be affected by the results of the proceedings including the parents or guardians of the child. 


\section{O. I. Tajudeen}

Part XV (Sections 171-185) provides for State Government support for children and families, including the provision of a range of services appropriate of the welfare and upbringing needs of children including further accommodation and maintenance for children looked after by it, as well as provision of advice and assistance for certain categories of children.

Much along the principle of creation of institutions for servicing the needs and welfare of the child, the Act, under Part XVI (Sections 186-190), provides for the establishment, registration, regulation and monitoring of Community Homes; Part XVII (Sections 191-194) similarly provides for Voluntary homes and Voluntary Organisations; Part XVIII (Sections 195-197) of the Act provide for Registered Children's Homes, while Part XIX (Sections 198 to 203) provides for the supervisory functions and responsibilities of the minister having responsibility for children in relation to the various children's Homes, which includes monitoring, provision of financial support, research and returns of information on the activities of these homes.

Part XX (Sections 204-238) of the Act provides for Child Justice Administration, which will now replace the Juvenile Justice Administration, which has been in existence for several decades in Nigeria. The provisions in this part prohibit the subjection of any child to the criminal justice process, and guarantees the due process to any child subjected to the Child Justice system under the Act at all stages of investigation, adjudication, and disposition of the child. In this regard, the Act has sought to apply (the principles contained in the UN Standard Minimum Rules for the Administration of Juvenile Justice (otherwise known as the Beijing Rules) in Child Justice Administration in Nigeria.

The functions of the Committee, among others, are to initiate actions that shall ensure the observance and popularisation of the rights and welfare of the child as provided for in the Act, the UN Convention on the Rights of the Child, the OAU Charter on the Rights and Welfare of the Child, the Dakar Consensus and National Programme of Action, the Declaration of the World Summit for Children, and such other international instruments relating to children to which Nigeria is a signatory; continually keep under review, the state of implementation of the rights of the child; prepare and submit periodic reports on the state of implementation of the rights of the child to the Federal Government, African Union, ECOWAS and the United Nations.

Finally, Part XXIV (Sections 272-279) of the Act variously provides for service of documents, supremacy of the provisions of the Act over those of all other laws relating to children in cases of inconsistency, interpretation and citation of the Act. The Act has eleven Schedules which contain rules for regulating the functioning and management of the various mechanisms and institutions created under the Act.

The Child Rights Act provides for a ten-year sentence for the trafficking of children for the purposes of hawking, begging, prostitution, pornography, labour, under slave like conditions and activities related to illicit drugs.

\section{Conclusion}

In this paper the writer has examined the legal framework for the protection of child rights in Nigeria. The Nigerian Child Rights Act was also considered in detail. It is evident from the above overview of the rationale, structure and contents of the Child Rights Act 2003, coupled with the analysis of state obligations to promote and protect 
children's rights, that in its rights/responsibilities approach, the Act is constitutionally and culturally sensitive, progressive, compatible, relevant, problem solving and above all, in the best interest and welfare of the Nigerian Child.

\section{Selected Bibliography}

1. Convention on the Rights of the Child.

http://www.hakani.org/en/convention/convention_rights_child.pdf

2. Nigerian Child Rights Act, 2003. 